NASA/TM-1998-206983

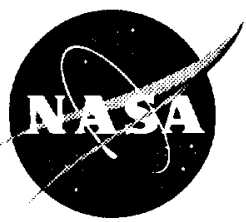

\title{
Evaluation of Capacitors at Cryogenic Temperatures for Space Applications
}

Richard L. Patterson

Lewis Research Center, Cleveland, Ohio

Ahmad Hammoud and Scott S. Gerber

NYMA, Inc., Brook Park, Ohio

Prepared for the

1998 International Symposium on Electrical Insulation cosponsored by the IEEE and AP-S/URSI

Washington, DC, June 7-10, 1998

National Aeronautics and

Space Administration

Lewis Research Center 


\section{Acknowledgments}

This work was supported by NASA Lewis Research Center, Contract No. 27186, Task Order 5406-1.

This report is a preprint of a paper intended for presentation at a conference. Because

of changes that may be made before formal publication, this preprint is made available with the understanding that it will not be cited or reproduced without the

permission of the author.

Available from

NASA Center for Aerospace Information

7121 Standard Drive

Hanover, MD 21076

Price Code: A02
National Technical Information Service 5287 Port Royal Road Springfield, VA 22100

Price Code: A02 


\title{
EVALUATION OF CAPACITORS AT CRYOGENIC TEMPERATURES FOR SPACE APPLICATIONS
}

\author{
Richard L. Patterson \\ NASA Lewis Research Center \\ Cleveland, Ohio 44135 \\ Ahmad Hammoud and Scott S. Gerber \\ NYMA, Inc. \\ Brook Park, Ohio 44142
}

\begin{abstract}
Advanced electronic systems designed for use in planetary exploration missions must operate efficiently and reliably under the extreme low temperatures of deep space environment. In addition, spacecraft power electronics capable of low temperature operation will greatly simplify the thermal management system by eliminating the need for heating units and associated equipment and thereby reduce the size and weight of the overall power system. In this study, film, mica, solid tantalum and electric double layer capacitors were evaluated as a function of temperature in terms of their dielectric properties. These properties included capacitance stability and dielectric loss in the frequency range of $50 \mathrm{~Hz}$ to $100 \mathrm{kHz}$. DC leakage current measurements were also performed on the capacitors. The results obtained are discussed and conclusions are made concerning the suitability of the capacitors investigated for low temperature applications.
\end{abstract}

\section{INTRODUCTION}

In many future NASA missions such as planetary exploration, space probes, and communication satellites, high power electrical components and systems must operate reliably and efficiently in very cold environments. Electronic instrumentation and power systems deployed near Pluto will encounter temperatures as low as $-229^{\circ} \mathrm{C}[1]$.

Power electronics capable of low temperature operation will not only survive the harsh environments, but will reduce system size and weight by eliminating the need for radioactive heating units and associated equipment, thereby reducing launch cost, improving reliability and lifetime [2], and increasing energy densities.

Low temperature electronic components will also have a great influence in many terrestrial applications such as cryogenic medical instrumentation, superconducting magnetic energy storage and distribution systems for the power industry, magnetic levitation transportation systems [3], as well as NASA's Arctic and Antarctic missions.
Commercial off-the-shelf components are usually limited in their temperature handling capability due to limitations in the materials being used or due to the inherent design and manufacturing processes and techniques. New materials and advanced components capable of providing more efficient and reliable operation at low temperatures coupled with improvement in design topologies, therefore, constitute a major challenge in the development of advanced power systems suitable for use in deep space and other harsh environments.

Research programs to design and develop lightweight, reliable wide temperature power systems for space-based applications are being performed at the NASA Lewis Research Center [3-4]. Efforts have been made to design and develop power capacitors capable of wide temperature operation. In this work, polypropylene and polycarbonate film capacitors, mica, solid tantalum, and electric double layer capacitors were characterized in terms of their dielectric properties at room temperature before and after exposure to liquid nitrogen. Subsequent testing included in-situ characterization of the capacitors in liquid nitrogen. The properties investigated included capacitance stability and dielectric loss (dissipation factor) in the frequency range of 50 $\mathrm{Hz}$ to $100 \mathrm{kHz}$. DC leakage current measurements were also performed on the capacitors. The results obtained are presented and discussed in this paper.

\section{EXPERIMENTAL PROCEDURE}

Eleven different capacitors from various manufacturers were investigated in this study. These include one polycarbonate and three polypropylene film capacitors, one mica, one solid tantalum, and five different electric double layer (EDL) capacitors. The polypropylene capacitors were different in their power handling capability and device encapsulation. Some of the capacitor specifications, which include capacitance, tolerance, voltage rating, dissipation factor, equivalent series resistance (ESR), and operating temperature, are listed in Table I. 
Table I. Capacitors Specifications

\begin{tabular}{|l|c|c|c|c|c|c|}
\hline \multicolumn{1}{|c|}{ Type } & Capacitance & $\begin{array}{c}\text { Capacitance } \\
\text { Tolerance (\%) }\end{array}$ & $\begin{array}{c}\text { Voltage } \\
(\text { VDC) }\end{array}$ & $\begin{array}{c}\text { Dissipation } \\
\text { Factor (\%) }\end{array}$ & $\begin{array}{c}\text { ESR } \\
(\Omega)\end{array}$ & $\begin{array}{c}\text { Operating } \\
\text { Temp. }\left({ }^{\circ} \mathrm{C}\right)\end{array}$ \\
\hline Polypropylene 1 & $1.0 \mu \mathrm{F}$ & \pm 10 & 100 & $<1 \times 10^{-3}$ & - & -55 to +105 \\
\hline Polypropylene 2 & $0.1 \mu \mathrm{F}$ & \pm 5 & 400 & $<1 \times 10^{-3}$ & - & -55 to +105 \\
\hline Polypropylene 3 & $1.0 \mu \mathrm{F}$ & 5 & 100 & $<1 \times 10^{-3}$ & - & -55 to +105 \\
\hline Polycarbonate & $1.0 \mu \mathrm{F}$ & -5 & 100 & $<2.5 \times 10^{-3}$ & - & -55 to +125 \\
\hline Mica & $0.01 \mu \mathrm{F}$ & \pm 5 & 500 & - & - & -55 to +150 \\
\hline Solid Tantalum & $0.1 \mu \mathrm{F}$ & \pm 10 & 100 & $<2 \times 10^{-2}$ & - & -55 to +85 \\
\hline EDL 1 & $0.1 \mathrm{~F}$ & $+80,-20$ & 5.5 & - & $<6.5$ & -40 to +70 \\
\hline EDL 2 & $0.1 \mathrm{~F}$ & - & 5.5 & - & $<50$ & -40 to +85 \\
\hline EDL 3 & $1.0 \mathrm{~F}$ & \pm 30 & 5.5 & - & $<30$ & -25 to +85 \\
\hline EDL 4 & $1.0 \mathrm{~F}$ & +20 & 5.5 & - & $<2$ & -55 to +85 \\
\hline EDL 5 & $7.5 \mathrm{~F}$ & - & 2.5 & - & $<0.035$ & -40 to +70 \\
\hline
\end{tabular}

Aging of the capacitors at cryogenic temperature was achieved by soaking them in a liquid nitrogen-filled dewar for a period of 24 hours. The capacitors were then allowed to stabilize to room temperature, prior to testing, for about 3 hours. In-situ characterization was also performed on the same aged capacitors by soaking them in the dewar for a duration of one hour before performing any measurement.

The capacitance and dissipation factor of the non-EDL capacitors were obtained in the frequency range of $50 \mathrm{~Hz}$ to $100 \mathrm{kHz}$ using a Genrad Model 1689 Precision RLC Digibridge. This programmable Digibridge was used in an automated mode using a computer. The capacitance of the EDL capacitors was obtained through the measurement of their respective charging time constant. The high capacitance values of these capacitors were beyond the measuring capability of the Digibridge and, hence, a DC charging circuit was designed and configured to charge the various capacitors. A Tektronix DSA 602A Digital Signal Analyzer was used to allow the capture of their charging characteristic profiles. Four-lead connection to each device under test was used in these experiments to ensure accurate measurements by minimizing parasitic effects and erroneous signals

A Keithley Model 237 Source Measure Unit was used to perform the DC leakage current measurements. Leakage currents were recorded after an electrification time of 20 minutes in accordance with the ASTM standards. This designated electrification allows the capacitors to fully charge and the leakage current to stabilize. After each leakage current measurement was made, the capacitors were discharged.

\section{RESULTS}

Three capacitors of each type were subjected to characterization. All capacitors of the same type displayed similar behavior upon testing and showed good reproducibility. Therefore, the data presented and discussed in this paper was obtained for one capacitor of each type. This data was representative of all the units tested of the same type.

Table II depicts the capacitance and the dissipation factor (DF) for the non-EDL capacitors for control (as-received), aged (after soaking in liquid nitrogen), and in-situ (devices tested while in liquid nitrogen) conditions. Although the dielectric characterization of these capacitors was obtained in the frequency range of $50 \mathrm{~Hz}$ to $100 \mathrm{kHz}$, almost all of the capacitors displayed similar trend in their behavior as a function of the test frequency. Thus, the data reported in Table II is for selected frequencies of $1 \mathrm{kHz}, 20 \mathrm{kHz}$, and $50 \mathrm{kHz}$. It can be clearly seen that all capacitors, except the solid tantalum ones, have shown good stability in their capacitance and dissipation factor at or after exposure to the cryogenic temperature. The solid tantalum capacitor, however, exhibited a modest decrease in its capacitance and a significant increase in its dissipation factor only when tested at liquid nitrogen $\left(-196{ }^{\circ} \mathrm{C}\right)$ temperature. These effects were more profound at high frequencies.

The DC leakage current of the non-EDL capacitors is shown in Table III. In general, there is no effect of aging on this property of the capacitors. When the measurements were carried out at liquid nitrogen, however, the leakage current seemed to decrease from its original value for all the capacitors. It can be postulated that the very cold temperature environment might have affected the ionic mobility or the 
electronic conductivity, and might have influenced molecular dipole relaxation and other interaction phenomena.

The capacitance and the DC leakage current of the EDL capacitors are shown in Table IV. It can be clearly seen that all capacitors exhibited minimal change in these properties after exposure to liquid nitrogen. In fact, the values of the leakage current attained for most of them were somehow slightly less than their original (pre-exposure) values.

Although aging of these types of capacitors in liquid nitrogen did not produce any significant effect on their dielectric properties, subsequent testing at liquid nitrogen temperature revealed that these devices lose their functional capability at that temperature. During these measurements, the capacitors under test attained instantly the full applied charging voltage. Thus, the charging time constants could not be determined. This result was expected due to the nature of the electrolytes in these types of capacitors and the temperature dependency of their ionic conductivity. Also, the test temperature exceeded, by far, their temperature rating. It is important to note that these capacitors, however, seem to recover their functionality after removal of the liquid nitrogen environment.

\section{CONCLUSIONS}

The results obtained in this work indicate that the effect of low temperature on the dielectric properties of capacitors depends mainly on the dielectric medium being used. For example, while polypropylene, polycarbonate, and mica capacitors showed excellent stability when tested at liquid nitrogen, the solid tantalum capacitor exhibited an increase in its dielectric loss at that temperature. Most of the EDL capacitors experienced no change with aging but seemed not to function at the extreme temperature. More testing efforts are currently underway to characterize all of the above capacitors as a function of temperature from room to $-200^{\circ} \mathrm{C}$. These and further experimental studies are required to better and fully characterize these and other capacitors for potential use in low or wide temperature environments.

Table II. Capacitance and Dissipation Factor (DF) of non-EDL Capacitors

\begin{tabular}{|c|c|c|c|c|c|c|c|}
\hline & & \multicolumn{2}{|c|}{ Control } & \multicolumn{2}{|c|}{ Aged } & \multicolumn{2}{|c|}{ In-Situ } \\
\hline Type & $f(\mathrm{kHz})$ & $\mathbf{C}(\mu \mathrm{F})$ & DF $\left(\times 10^{-2}\right)$ & $\mathbf{C}(\mu \mathbf{F})$ & DF $\left(\times 10^{-2}\right)$ & $\mathbf{C}(\mu \mathrm{F})$ & $\overline{D F}\left(\times 10^{-2}\right)$ \\
\hline Polypropylene 1 & $\begin{array}{c}1 \\
20 \\
50\end{array}$ & $\begin{array}{l}0.99 \\
0.99 \\
0.99\end{array}$ & $\begin{array}{l}0.02 \\
0.18 \\
0.49\end{array}$ & $\begin{array}{l}0.97 \\
0.97 \\
0.97\end{array}$ & $\begin{array}{l}0.01 \\
0.09 \\
0.24\end{array}$ & $\begin{array}{l}1.0 \\
1.0 \\
1.0\end{array}$ & $\begin{array}{l}0.01 \\
0.08 \\
0.31\end{array}$ \\
\hline Polypropylene 2 & $\begin{array}{c}1 \\
20 \\
50\end{array}$ & $\begin{array}{l}0.098 \\
0.098 \\
0.098\end{array}$ & $\begin{array}{l}0.01 \\
0.05 \\
0.14\end{array}$ & $\begin{array}{l}0.098 \\
0.098 \\
0.098\end{array}$ & $\begin{array}{l}0.01 \\
0.06 \\
0.16\end{array}$ & $\begin{array}{l}0.1 \\
0.1 \\
0.1\end{array}$ & $\begin{array}{l}0.01 \\
0.02 \\
0.11\end{array}$ \\
\hline Polypropylene 3 & $\begin{array}{c}1 \\
20 \\
50\end{array}$ & $\begin{array}{l}0.99 \\
0.99 \\
0.98\end{array}$ & $\begin{array}{l}0.02 \\
0.20 \\
0.55\end{array}$ & $\begin{array}{l}0.99 \\
0.99 \\
0.99\end{array}$ & $\begin{array}{l}0.02 \\
0.21 \\
0.54\end{array}$ & $\begin{array}{l}1.0 \\
1.0 \\
1.0\end{array}$ & $\begin{array}{l}0.01 \\
0.08 \\
0.29\end{array}$ \\
\hline Polycarbonate & $\begin{array}{c}1 \\
20 \\
50\end{array}$ & $\begin{array}{l}0.97 \\
0.97 \\
0.96\end{array}$ & $\begin{array}{l}0.08 \\
0.29 \\
0.57\end{array}$ & $\begin{array}{l}0.97 \\
0.96 \\
0.96\end{array}$ & $\begin{array}{l}0.09 \\
0.31 \\
0.61\end{array}$ & $\begin{array}{l}0.92 \\
0.92 \\
0.92\end{array}$ & $\begin{array}{l}0.05 \\
0.11 \\
0.33\end{array}$ \\
\hline Mica & $\begin{array}{c}1 \\
20 \\
50\end{array}$ & $\begin{array}{l}0.01 \\
0.01 \\
0.01\end{array}$ & $\begin{array}{l}0.05 \\
0.05 \\
0.10\end{array}$ & $\begin{array}{l}0.01 \\
0.01 \\
0.01\end{array}$ & $\begin{array}{l}0.03 \\
0.06 \\
0.08\end{array}$ & $\begin{array}{l}0.01 \\
0.01 \\
0.01\end{array}$ & $\begin{array}{l}0.01 \\
0.03 \\
0.08\end{array}$ \\
\hline Solid Tantalum & $\begin{array}{c}1 \\
20 \\
50\end{array}$ & $\begin{array}{l}0.099 \\
0.098 \\
0.098\end{array}$ & $\begin{array}{c}0.77 \\
8.90 \\
21.00\end{array}$ & $\begin{array}{l}0.099 \\
0.098 \\
0.098\end{array}$ & $\begin{array}{c}0.77 \\
9.10 \\
22.00\end{array}$ & $\begin{array}{l}0.095 \\
0.088 \\
0.067\end{array}$ & $\begin{array}{l}6.8 \\
119 \\
221\end{array}$ \\
\hline
\end{tabular}




\section{REFERENCES}

[1] B. Ray and R. L. Patterson, "Wide Temperature Operation of a PWM DC-DC Converter," IEEE Industry Applications Society Conference, Orlando, FL, Oct. 8-12, 1995.

[2] R. K. Kirschman, "Low Temperature Electronics Device Operation," The Electro-chemical Society PV 91-14, 1991.
[3] B. Ray, S. S. Gerber, R. L. Patterson, and I. T. Myers, "Liquid Nitrogen Temperature Operation of a Switching Power Converter," Low Temperature Electronics and High Temperature Superconductivity Symposium, Reno, NV, May 21-16, 1995.

[4] A. N. Hammoud, E. D. Baumann, I. T. Myers, and E. Overton, "High Temperature Power Electronics for Space," presented at the First International High Temperature Electronics Conference, Albuquerque, NM, June 16-20, 1991.

Table III. Leakage Current (nA) of non-EDL Capacitors

\begin{tabular}{|l|c|c|c|}
\hline Type & Control & Aged & In-Situ \\
\hline Polypropylene 1 & 1.80 & 1.20 & 0.02 \\
\hline Polypropylene 2 & 8.30 & 2.45 & 1.20 \\
\hline Polypropylene 3 & 9.50 & 5.00 & 0.06 \\
\hline Polycarbonate & 3.20 & 2.64 & 0.14 \\
\hline Mica & 7.10 & 10.80 & 0.10 \\
\hline Solid Tantalum & 27.50 & 22.60 & 0.08 \\
\hline
\end{tabular}

Table IV. Capacitance and Leakage Current of EDL Capacitors

\begin{tabular}{|c|c|c|c|c|}
\cline { 2 - 5 } \multicolumn{1}{c|}{} & \multicolumn{2}{c|}{ Control } & \multicolumn{2}{c|}{ Aged } \\
\hline Type & $\mathbf{C}(\mathbf{F})$ & $\mathbf{I}(\mu \mathbf{A})$ & 0.10 & $\mathbf{I}(\mu \mathbf{A})$ \\
\hline EDL 1 & 0.10 & 90 & 0.11 & 54 \\
\hline EDL 2 & 0.10 & 50 & 1.1 & 22 \\
\hline EDL 3 & 0.92 & 220 & 0.92 & 330 \\
\hline EDL 4 & 0.94 & 470 & 8.9 & 4073 \\
\hline EDL 5 & 8.7 & 5060 & & \\
\hline
\end{tabular}





\begin{tabular}{|c|c|c|c|}
\hline \multicolumn{3}{|c|}{ REPORT DOCUMENTATION PAGE } & $\begin{array}{l}\text { Form Approved } \\
\text { OMB No. 0704-0188 }\end{array}$ \\
\hline \multicolumn{4}{|c|}{ 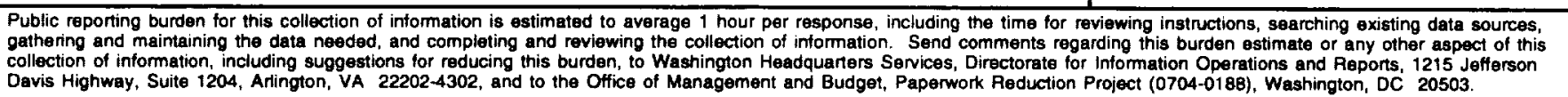 } \\
\hline 1. AGENCY USE ONLY (Leave blank) & $\begin{array}{r}\text { 2. REPORT DATE } \\
\text { April } 1998\end{array}$ & 3. 1 & $\begin{array}{l}\text { VD DATES COVERED } \\
\text { echnical Memorandum }\end{array}$ \\
\hline $\begin{array}{l}\text { 4. TITLE AND SUBTITLE } \\
\text { Evaluation of Capacitors at } C\end{array}$ & ggenic Temperatures $f$ & App & 5. FUNDING NUMBERS \\
\hline $\begin{array}{l}\text { 6. AUTHOR(S) } \\
\text { Richard L. Patterson, Ahmad }\end{array}$ & ammoud, and Scott $S$. & & $W U-632-1 \mathrm{~A}-1 \mathrm{H}-00$ \\
\hline $\begin{array}{l}\text { 7. PERForming OAGANIZATION NA } \\
\text { National Aeronautics and Sp } \\
\text { Lewis Research Center } \\
\text { Cleveland, Ohio } 44135-319\end{array}$ & $\begin{array}{l}\text { S) AND ADDRESS(ES) } \\
\text { Administration }\end{array}$ & & $\begin{array}{l}\text { 8. PERFOAMING ORGANIZATION } \\
\text { REPORT NUMBER } \\
\text { E-11145 }\end{array}$ \\
\hline $\begin{array}{l}\text { 9. SPONSORINGMONITORING AGEN } \\
\text { National Aeronautics and Sp } \\
\text { Washington, DC 20546-000 }\end{array}$ & $\begin{array}{l}\text { NAME(S) AND ADDRESS } \\
\text { Administration }\end{array}$ & & $\begin{array}{l}\text { 10. SPONSORINGMONITORING } \\
\text { AGENCY REPORT NUMBER } \\
\text { NASA TM-1998-206983 }\end{array}$ \\
\hline $\begin{array}{l}\text { 11. SUPPLEMENTARY NOTES } \\
\text { Prepared for the } 1998 \text { Interna } \\
\text { Washington, DC, June 7-10, } \\
\text { Gerber, NYMA, Inc., 2001 B } \\
\text { person, Richard L. Patterson, }\end{array}$ & $\begin{array}{l}\text { al Symposium on El } \\
\text { 8. Richard L. Patters } \\
\text { Park, Ohio } 44142 \text { ( } \\
\text { anization code } 5480 \text {, }\end{array}$ & & $\begin{array}{l}\text { by the IEEE and AP-S/URSI, } \\
\text { enter; Ahmad Hammoud and Scott S. } \\
\text { Contract NAS3-27186). Responsible }\end{array}$ \\
\hline
\end{tabular}
\begin{tabular}{l|l} 
12a. DISTRIBUTION/AVAILABILTYY STATEMENT & 12b. DISTRIBUTION CODE
\end{tabular}
Unclassified - Unlimited
Subject Categories: 33 and $20 \quad$ Distribution: Nonstandard
This publication is available from the NASA Center for AeroSpace Information, (301) 621-0390.
13. ABSTAACT (Maximum 200 words)
Advanced electronic systems designed for use in planetary exploration missions must operate efficiently and reliably under the extreme cold temperatures of deep space environment. In addition, spacecraft power electronics capable of cold temperature operation will greatly simplify the thermal management system by eliminating the need for heating units and associated equipment and thereby reduce the size and weight of the overall power system. In this study, film, mica, solid tantalum and electric double layer capacitors were evaluated as a function of temperature from room to liquid nitrogen in terms of their dielectric properties. These properties included capacitance stability and dielectric loss in the frequency range of $50 \mathrm{~Hz}$ to $100 \mathrm{kHz}$. DC leakage current measurements were also performed on the capacitors. The results obtained are discussed and conclusions are made concerning the suitability of the capacitors investigated for low tempera- ture applications.

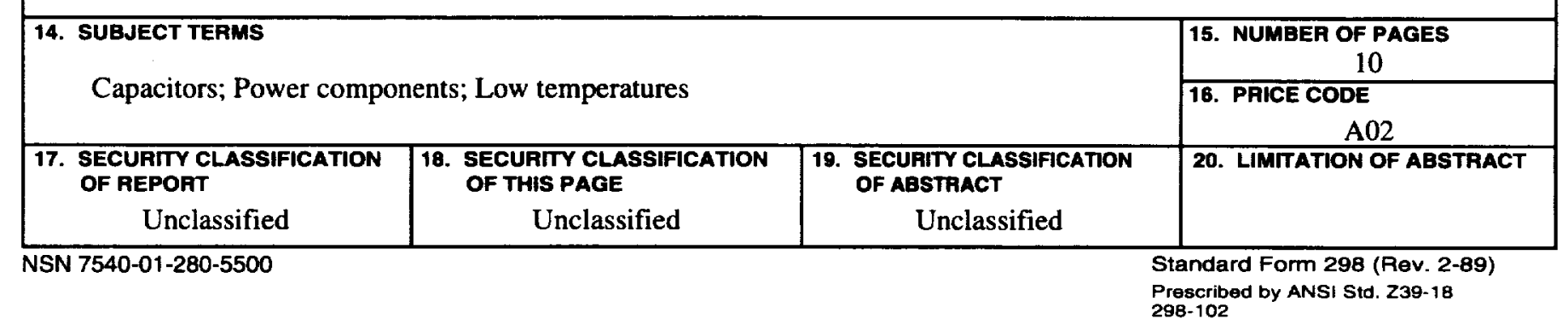

